\title{
Inhibition of natural gas hydrate in the system containing salts and crude oil
}

\author{
Mu, Liang; von Solms, Nicolas
}

Published in:

Journal of Petroleum Science and Engineering

Link to article, DOI:

10.1016/j.petrol.2020.106940

Publication date:

2020

Document Version

Peer reviewed version

Link back to DTU Orbit

Citation (APA):

Mu, L., \& von Solms, N. (2020). Inhibition of natural gas hydrate in the system containing salts and crude oil. Journal of Petroleum Science and Engineering, 188, [106940]. https://doi.org/10.1016/j.petrol.2020.106940

\section{General rights}

Copyright and moral rights for the publications made accessible in the public portal are retained by the authors and/or other copyright owners and it is a condition of accessing publications that users recognise and abide by the legal requirements associated with these rights.

- Users may download and print one copy of any publication from the public portal for the purpose of private study or research.

- You may not further distribute the material or use it for any profit-making activity or commercial gain

- You may freely distribute the URL identifying the publication in the public portal

If you believe that this document breaches copyright please contact us providing details, and we will remove access to the work immediately and investigate your claim. 


\title{
Inhibition of synthetic natural gas hydrate by an antifreeze protein in the system containing salts and crude oil
}

\author{
Liang $\mathrm{Mu}$ and Nicolas von Solms*
}

\begin{abstract}
Department of Chemical and Biochemical Engineering, Center for Energy Resource Engineering (CERE), Technical University of Denmark, DK-2800 Kgs. Lyngby, Denmark
\end{abstract}

\begin{abstract}
Antifreeze proteins are becoming increasingly attractive as a kind of biological hydrate inhibitors. In this work, the inhibition performance of a new antifreeze protein (mSA-AFP) on synthetic natural gas (SNG) hydrate nucleation in the case of existing salts and crude oil was investigated using a rocking cell apparatus. In addition, three kinds of environment friendly inhibitors (starch, chitosan and glycine) as well as a commercial inhibitor (PVP) were tested for comparison. The results showed that $2250 \mathrm{pm}$ mSA-AFP can inhibit SNG hydrate formation more effectively than PVP in various systems (pure water, salt water, salt water +15 vol $\%$ crude oil). Starch, chitosan and glycine present mild inhibition ability on SNG hydrate nucleation. The inhibition strength of various chemicals can be ranked as follows: starch $<$ chitosan $<$ glycine $<$ PVP $<$ mSA-AFP. The SNG hydrate crystal growth and decomposition process were investigated, it was found that mSA-AFP can decrease the SNG hydrate growth rate and production as well as the onset decomposition temperature, however, PVP increased the SNG hydrate production and onset decomposition temperature. For investigating if the results have dependence on experimental apparatus, the performance of various inhibitors were tested using a micro differential scanning calorimeter. It was found that the results are consistent with those obtained from the rocking cell apparatus. This study can provide detailed research information on the application of AFPs and contribute to understand hydrate formation and decomposition behavior for the system containing inhibitors in realistic conditions.
\end{abstract}




\section{Introduction}

Gas hydrates (or clathrate hydrates) are non-stoichiometric crystalline compounds in which suitable-sized guest molecules are trapped in cage-like frameworks formed by hydrogen-bonded water molecules under high pressure and low temperature conditions. ${ }^{1}$ It was reported that there are more than 130 compounds can form hydrates when coexisting with water, however, only three main kinds of hydrate structures are found: structure I (sI), structure II (sII), and structure H (sH). ${ }^{2}$ Since Hammerschmidt ${ }^{3}$ discovered the gas hydrates formation caused transmission line blockage in 1934, it is always a vexing problem for petroleum industry. In recent years, this situation is aggravated because oil and gas exploitation moves to deep water. In addition to the potential explosion hazards such as the Gulf of Mexico oil spill event, ${ }^{4}$ hydrate blockage can also cause great economic losses for oil and gas companies due to the necessary pipeline shutdown and recovery. In industry, this issue is usually dealt with by adding large amounts of thermodynamic inhibitors (THIs) such as methanol and glycols, which can shift the hydrate equilibrium conditions to higher pressures and lower temperatures. ${ }^{5}$ However, considering that the huge dosages of THIs (up to $50 \mathrm{wt} \%$ of the water phase and cost $\$ 220$ million per year $)^{6}$ as well as the accompanying environmental issues, the researchers gradually shifted their interest to the kinetic hydrate inhibitors (KHIs). ${ }^{7}$ This method is more attractive compared to THIs since it can be used at very low dosages (less than $1 \mathrm{wt} \%$ of the aqueous phase) to alleviate the hydrate blockage problem. KHIs do not prevent hydrate formation through changing hydrate equilibrium condition but retard the onset nucleation (or prolong crystal growth) long enough to avoid pipeline blockage.

KHIs are mainly water-soluble polymers containing hydrophobic and hydrophilic groups, ${ }^{8,9}$ the hydrophobic groups can enter hydrate cavities, while the hydrophilic groups contribute hydrogenbonding to water. Typical commercial KHIs (PVP and PVCap) include polymers and copolymers of 
$\mathrm{N}$-vinyl pyrrolidone and $\mathrm{N}$-vinyl caprolactam, ${ }^{10}$ however, these polymers have poor biodegradability and limit their application in seawater, that prompts researchers further to develop or seek environment friendly hydrate inhibitors. Sa et al. ${ }^{11}$ reported that amino acids with lower hydrophobicity can be used as KHIs to delay hydrate nucleation and growth. Xu et al. ${ }^{12}$ tested pectin as a novel natural $\mathrm{KHI}$, their results indicated that it can inhibit $\mathrm{CH}_{4}$ hydrate formation under a subcooling of $12.5{ }^{\circ} \mathrm{C}$, and the biodegradability improved $75 \%$ compared to PVCap. Lee et al. ${ }^{13}$ investigated the performance of cationic starches as hydrate inhibitors, they observed that the starches exhibit a weak inhibiting effect except for tapioca starch which could delay the induction time by an order of magnitude. $\mathrm{Xu}$ et al. ${ }^{14}$ investigated chitosan as green kinetic inhibitors for inhibiting $\mathrm{CH}_{4}$ and $\left(\mathrm{CH}_{4}+\mathrm{C}_{2} \mathrm{H}_{8}\right)$ gas hydrate formation, it was found that the induction time of gas hydrate formation evidently increased. In addition, antifreeze proteins (AFPs) as a kind of natural biological KHIs attracted more and more researchers' attention. ${ }^{15-25}$ Zeng et al. ${ }^{16}$ tested the inhibition performance of two AFPs from fish and insect on the formation of tetrahydrofuran (THF) hydrate, their results showed that these AFPs present a higher activities than PVP. In our preceding study, the effectiveness of a kind of AFPs from long-horned beetle (mSA-AFP) on $\mathrm{CH}_{4}$ hydrate formation were investigated using a rocking cell apparatus, the results indicated that $2250 \mathrm{ppm}$ mSA-AFP can inhibit $\mathrm{CH}_{4}$ hydrate more effectively than PVP-10. These studies confirmed that AFPs from different species have the ability to prevent gas hydrate formation. However, it is still far from the application of AFP in the field, because many factors such as gas and oil composition, sub cooling as well as salinity should be considered. In addition, some published literature data has apparatus dependence to some extent, for example, Xiao et al. ${ }^{26}$ evaluated the performance of five imidazolium-based ionic liquids using a micro differential scanning calorimeter (DSC), their results showed that these ionic liquids have good inhibition activity under subcooling of $25{ }^{\circ} \mathrm{C}$, they suggested that these ionic liquids can be as both thermodynamic and kinetic inhibitors. However, Villano et al. ${ }^{27}$ retested two of these ionic liquids 
with a high pressure sapphire cell, it was found that the two ionic liquids are poor KHIs when used alone at 5000-10000 ppm, while they can be used as good synergists for commercial KHIs. Therefore, it is necessary to obtain more reliable laboratory data before proceeding with filed application.

In this study, we mainly tested a kind of new AFPs (mSA-AFP) as well as three kinds of environment friendly inhibitors (starch, chitosan and glycine) in the case of existing salt and crude oil using a rocking cell apparatus, then comparing its performance on delaying SNG hydrate nucleation with commercial inhibitor (PVP). In addition, for reducing the dependence on testing apparatus, the effect of various inhibitors on SNG formation in salt water system were also conducted with a DSC apparatus. The results can provide detailed research information of mSA-AFP as a natural KHI under more realistic conditions.

\section{EXPERIMENTAL SECTION}

\subsection{Materials.}

Synthetic natural gas (SNG) was supplied by AGA company, its composition was listed in Table 1. Salt water was made by us with $3.5 \mathrm{wt} \% \mathrm{NaCl}$, and the details of chemicals used in this study are shown in Table 2. Antifreeze protein (mSA-AFP) originates from longhorn beetles, its preparation method has been reported in Kristiansen's work. ${ }^{28}$ PVP (polyvinylpyrrolidone), starch (from potato), glycine and chitosan are purchased from Sigma-Aldrich. Crude oil from the North Sea in Denmark was used in this work, which has a density $851.5 \mathrm{~kg} / \mathrm{m}^{3}$ (Table 3).

Table 1. The composition of synthetic natural gas (SNG) used in this study.

\begin{tabular}{cc}
\hline Component & Mole (\%) \\
\hline $\mathrm{CH}_{4}$ & 79.032 \\
$\mathrm{C}_{2} \mathrm{H}_{6}$ & 10.212 \\
$\mathrm{C}_{3} \mathrm{H}_{8}$ & 5.527 \\
\hline
\end{tabular}




\begin{tabular}{cc}
\hline$n-\mathrm{C}_{4} \mathrm{H}_{10}$ & 2.486 \\
$i-\mathrm{C}_{5} \mathrm{H}_{12}$ & 1.202 \\
$\mathrm{~N}_{2}$ & 0.298 \\
$\mathrm{CO}_{2}$ & 1.243 \\
\hline
\end{tabular}

Table 2. Chemicals used in this study.

\begin{tabular}{cccc}
\hline Chemicals & Form & Purity & Molecular mass \\
\hline mSA-AFP & Liquid & - & 25,660 \\
chitosan & Powder & $>99.0 \%$ & 50,000 \\
starch & Powder & $>99.3 \%$ & 12,000 \\
PVP & Powder & $>99.8 \%$ & 10,000 \\
glycine & Powder & $>99.0 \%$ & 75.07 \\
\hline
\end{tabular}

Table 3. The composition of crude oil used in this study.

\begin{tabular}{cc}
\hline Component & Mole (\%) \\
\hline $\mathrm{CH}_{4}$ & 0.04 \\
$\mathrm{C}_{2} \mathrm{H}_{6}$ & 0.30 \\
$\mathrm{C}_{3} \mathrm{H}_{8}$ & 0.81 \\
$i-\mathrm{C}_{4} \mathrm{H}_{10}$ & 0.41 \\
$n-\mathrm{C}_{4} \mathrm{H}_{10}$ & 1.02 \\
$n e o-\mathrm{C}_{5} \mathrm{H}_{12}$ & 0.02 \\
$i-\mathrm{C}_{5} \mathrm{H}_{12}$ & 0.72 \\
$n-\mathrm{C}_{5} \mathrm{H}_{12}$ & 0.90 \\
$\mathrm{C}_{6}$ & 1.92 \\
$\mathrm{C}_{7}$ & 4.92 \\
$\mathrm{C}_{8}$ & 6.21 \\
$\mathrm{C}_{9}$ & 6.09 \\
$\mathrm{C}_{10+}$ & 76.64
\end{tabular}

2.2. Apparatus. 
A rocking cell apparatus (RC-5, showed in Figure 1) was used to test various KHIs in water and crude oil system. This setup has five separated cells, which can be used simultaneously and provide statistical information. The effective volume of each cell is $40 \mathrm{~cm}^{3}$ and the maximum working pressure is 200 bar. For agitating the solution, a stainless steel ball (Diameter: $17 \mathrm{~mm}$ ) is placed inside each cell, which can be rocked between an angle of $-45^{\circ}$ and $+45^{\circ}$ in a cooling bath (from $-20{ }^{\circ} \mathrm{C}$ to $+60{ }^{\circ} \mathrm{C}$ ). The pressure and temperature of each cell were recorded in computer by a data acquisition system. The detailed description of this setup can be found in our preceding work. ${ }^{29-31}$

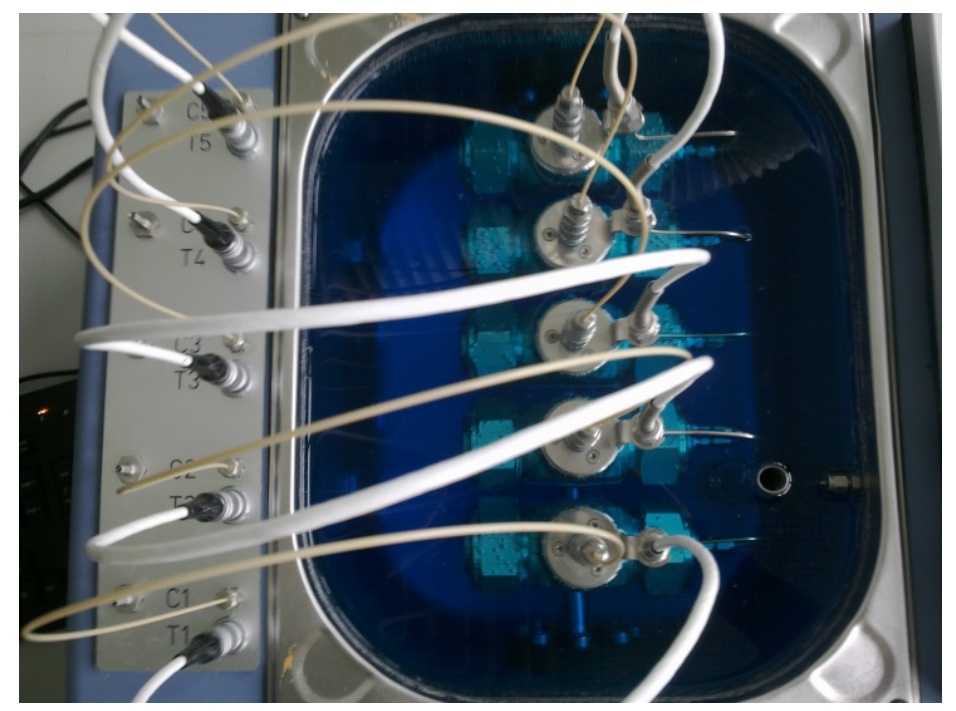

Figure 1. The rocking cell apparatus used in this work.

\subsection{Method.}

Before performing the experiments, the cells are washed with acetone and distilled water then dried with air flow. Each cell was loaded with $10 \mathrm{~mL}$ tested solution then installed in the apparatus. To eliminate air in the cells and external piping, they were evacuated using a vacuum pump. Then the cells were pressurized with SNG to 100 bar, starting the rocking cells at 20 rocks/min in the angle range of $-40^{\circ}$ and $+40^{\circ}$. A temperature ramping method was used to test the onset nucleation and dissociation point: first cooling from 25.0 to $1.0{ }^{\circ} \mathrm{C}$ at $0.1{ }^{\circ} \mathrm{C} / \mathrm{min}$, then heating from 1.0 to $25.0{ }^{\circ} \mathrm{C}$ at 
the same rate. Typical pressure and temperature curves in one group test are shown in Figure 2. The onset nucleation and decomposition temperatures can be identified by a sudden pressure dropping and rising, respectively (Figure 3). The detailed introduction of experimental method has been reported in our previous publications. ${ }^{29-31}$

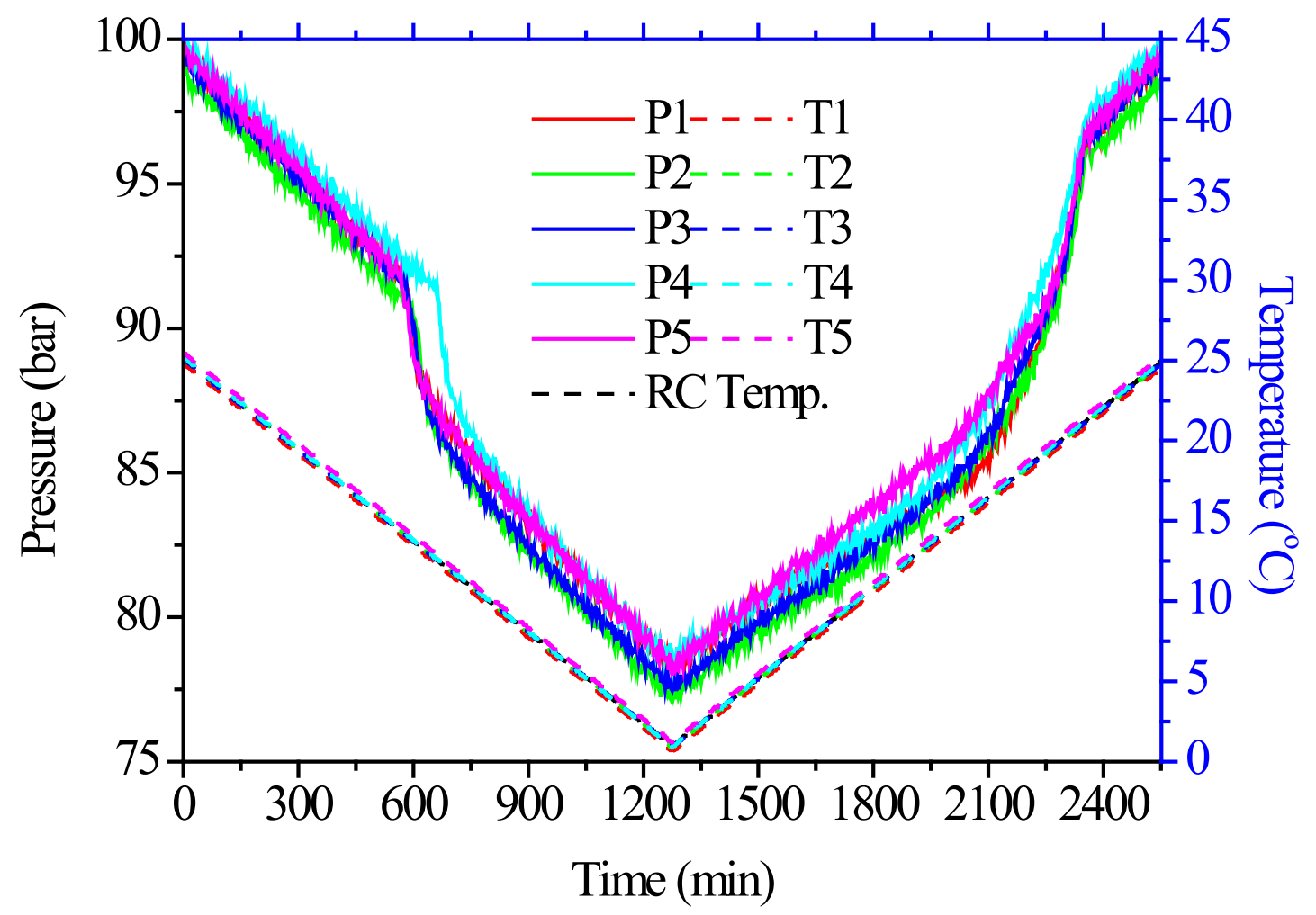

Figure 2. Typical pressure and temperature curves of five cells in one group test. 


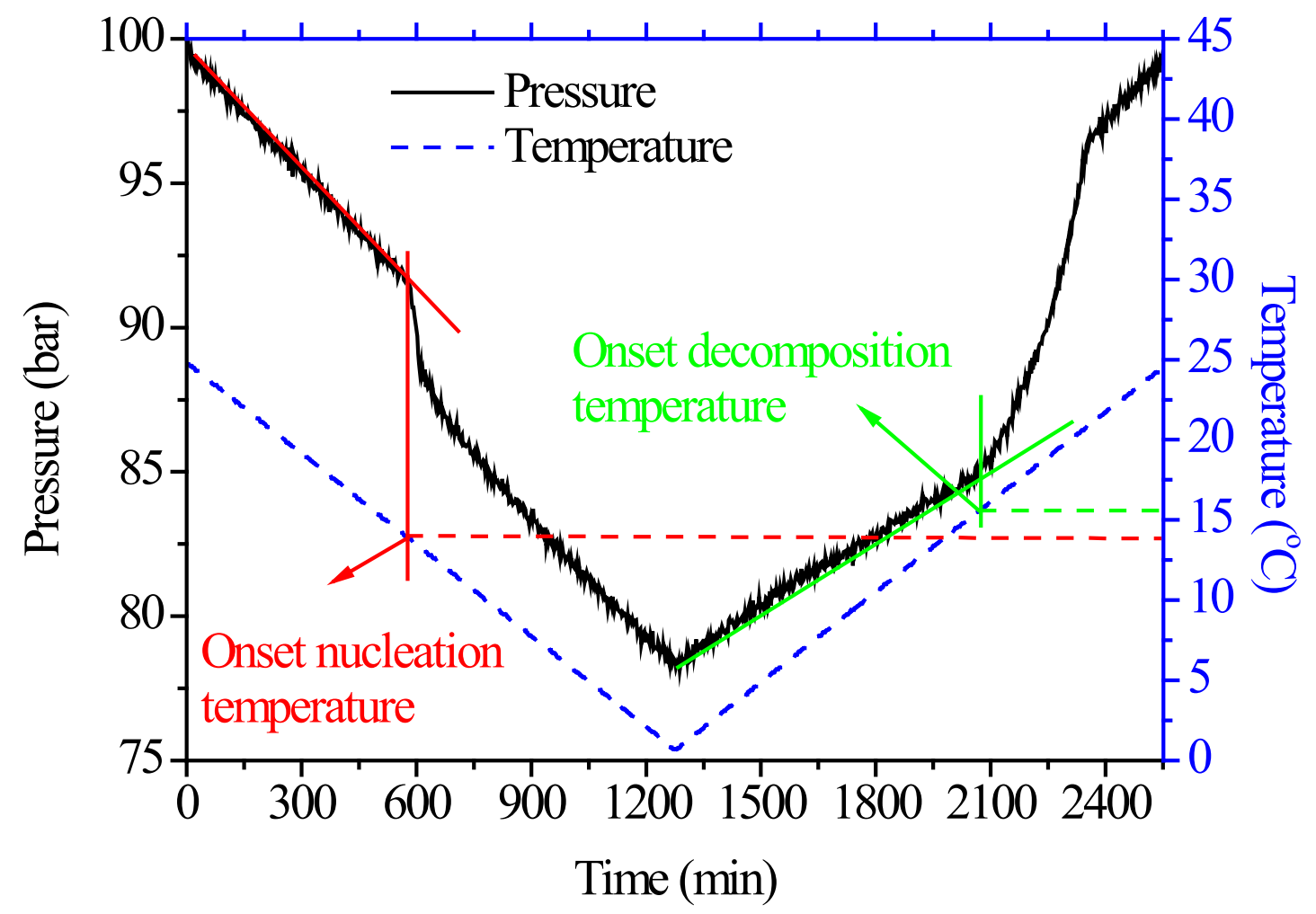

Figure 3. Determination of onset nucleation and decomposition temperatures.

\section{Results and discussion}

\subsection{The inhibition of SNG hydrate nucleation in pure water or salt water}

In temperature ramping test, the performance of various inhibitors can be expressed as their ability of lowering the onset nucleation temperature, therefore, the uninhibited system were first tested for comparison. The average onset nucleation temperature of SNG hydrate in pure water system occurred at $17.9{ }^{\circ} \mathrm{C}$, while it decreased to $15.8{ }^{\circ} \mathrm{C}$ in salt water system containing $3.5 \mathrm{wt} \% \mathrm{NaCl}$. This phenomenon is normal because some salts can change hydrate equilibrium condition by decreasing the water activity. ${ }^{1}$ Table 4 shows the test results of various inhibitors, the relative standard deviation was between $0.76-1.87 \%$ (standard deviation $0.12-0.25{ }^{\circ} \mathrm{C}$ ), which indicated our tests have a good repeatability. The adding of $2250 \mathrm{ppm} \mathrm{mSA}-\mathrm{AFP}$ in pure water and salt water system decreased their 
onset nucleation temperatures to 12.7 and $10.3{ }^{\circ} \mathrm{C}$, respectively, which suggested that mSA-AFP can effectively retard SNG hydrate nucleation. In this work, all the experiments were conducted under the same cooling rate, therefore, the inhibition strength of KHIs can be expressed as the difference of average onset nucleation temperatures in the uninhibited and inhibited system. As shown in Figure 4, the tested inhibitors can be ranked as follows: 1 , pure water system: $\operatorname{starch}\left(0.8^{\circ} \mathrm{C}\right)<\operatorname{chitosan}\left(1.1{ }^{\circ} \mathrm{C}\right)$ $<$ glycine $\left(1.9^{\circ} \mathrm{C}\right)<\operatorname{PVP}\left(4.6^{\circ} \mathrm{C}\right)<\operatorname{mSA}-\operatorname{AFP}\left(5.2^{\circ} \mathrm{C}\right) ; 2$, salt water system: $\operatorname{starch}\left(1.0^{\circ} \mathrm{C}\right)<\operatorname{chitosan}$ $\left(1.3^{\circ} \mathrm{C}\right)<$ glycine $\left(2.2^{\circ} \mathrm{C}\right)<\operatorname{PVP}\left(4.9^{\circ} \mathrm{C}\right)<\operatorname{mSA}-\operatorname{AFP}\left(5.5^{\circ} \mathrm{C}\right)$. It should be noted that the inhibition strength in this study is different with the subcooling data reported in literature, that was calculated by subtracting the actual formation temperature of hydrate in the inhibited system from its H-L-V three phase equilibrium temperature in the uninhibited system. Therefore, the bearable subcooling of the tested inhibitors in this work would be higher than their inhibition strength. By analyzing the test results, it can be observed that the coexistence of salts and inhibitors has a slightly cumulative effect on delaying SNG hydrate nucleation instead of weakening their inhibition activity. The performance of 2250 ppm mSA-AFP was more effective than commercial inhibitor PVP in pure water and salt water system. In addition, $2250 \mathrm{ppm}$ starch, glycine and chitosan showed mild inhibition activity on inhibiting SNG hydrate nucleation.

Table 4. The average onset nucleation temperatures of SNG hydrate in pure water and salt water system.

\begin{tabular}{ccccccccc}
\hline KHIs & $\begin{array}{c}\text { Number of } \\
\text { tests }\end{array}$ & $\begin{array}{c}\text { Concentration } \\
(\mathrm{ppm})\end{array}$ & $\begin{array}{c}T_{\mathrm{o}} \\
\left({ }^{\circ} \mathrm{C}\right)\end{array}$ & $\begin{array}{c}\text { SD } \\
\left({ }^{\circ} \mathrm{C}\right)\end{array}$ & $\begin{array}{c}\text { RSD } \\
(\%)\end{array}$ & $\begin{array}{c}T_{\mathrm{o}} \\
\left({ }^{\circ} \mathrm{C}\right)\end{array}$ & $\begin{array}{c}\text { SD } \\
\left({ }^{\circ} \mathrm{C}\right)\end{array}$ & $\begin{array}{c}\text { RSD } \\
(\%)\end{array}$ \\
\cline { 3 - 8 } & & & \multicolumn{3}{c}{ Pure water } & \multicolumn{3}{c}{ Salt water } \\
No KHIs & 5 & - & 17.9 & 0.21 & 1.17 & 15.8 & 0.18 & 1.15 \\
mSA-AFP & 1 & 2250 & 12.7 & - & - & 10.3 & - & - \\
chitosan & 5 & 2250 & 16.8 & 0.16 & 0.96 & 14.5 & 0.21 & 1.48 \\
starch & 5 & 2250 & 17.1 & 0.23 & 1.37 & 14.8 & 0.16 & 1.08 \\
PVP & 9 & 2250 & 13.3 & 0.16 & 1.23 & 10.9 & 0.18 & 1.64 \\
glycine & 5 & 2250 & 16.0 & 0.12 & 0.76 & 13.6 & 0.25 & 1.87 \\
\hline
\end{tabular}

${ }^{*} T_{\mathrm{o}}$ is average onset nucleation temperature, SD is standard deviation, RSD is relative standard deviation. Only one test was performed due to the limited amount of mSA-AFP, similarly hereinafter. 


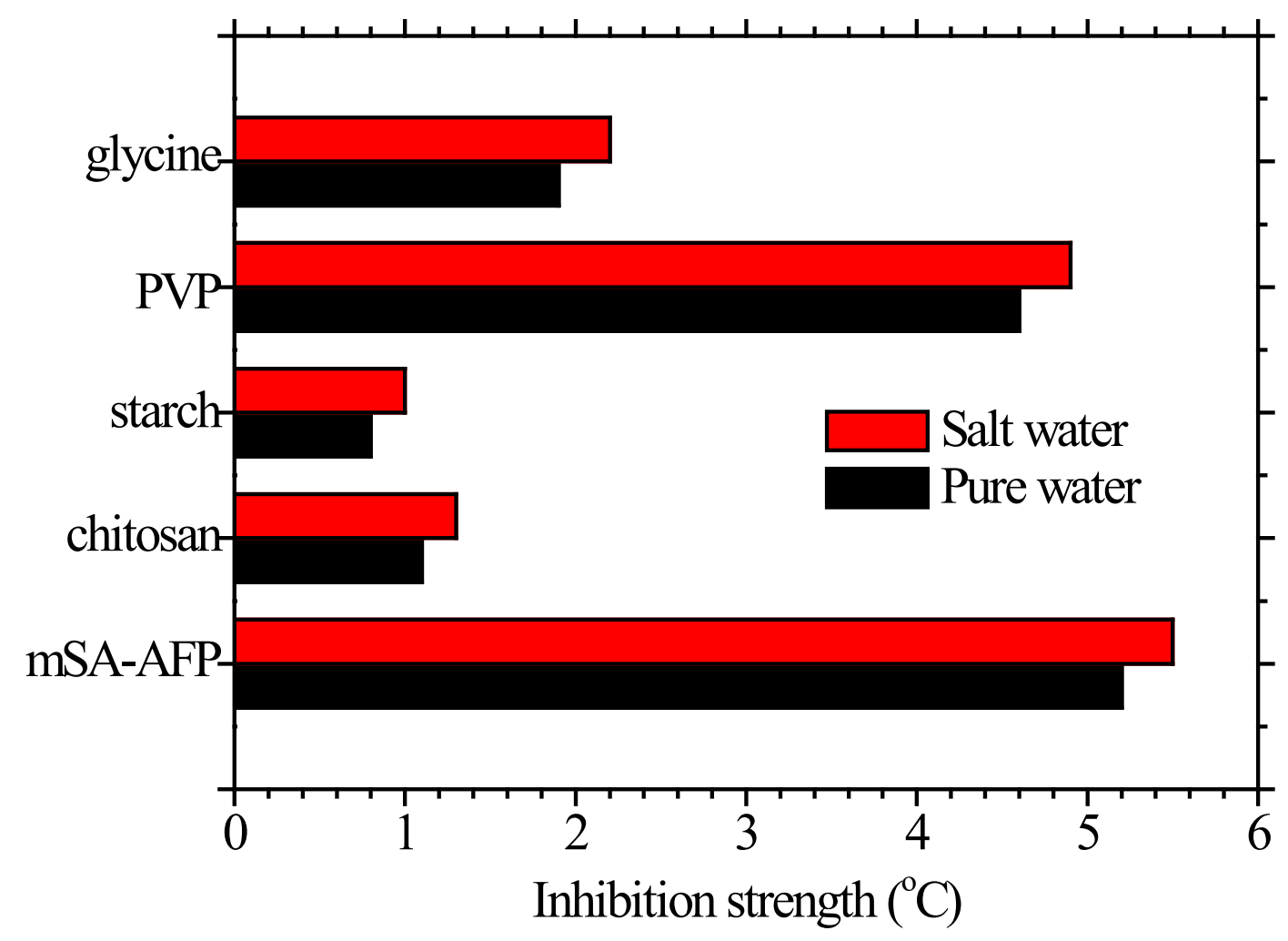

Figure 4. The inhibition strength of various chemicals in pure water and salt water system.

\subsection{The inhibition of SNG hydrate in the system containing crude oil}

For investigating the performance of mSA-AFP in more realistic conditions, the onset nucleation temperature of SNG hydrate in (salt water $+15 \mathrm{vol} \%$ crude oil) system was measured (Table 5). It was found that 15 vol $\%$ crude oil decreased the onset nucleation temperature $1.5{ }^{\circ} \mathrm{C}$ compared to salt water, which indicated that the presence of crude oil can contribute to prevent SNG hydrate nucleation. We speculated one reason might be that there are some components in crude oil can delay hydrate nucleation, another possible reason is that the solubility of SNG in crude oil is higher than water, leading to more heavy components dissolved in oil phase and the concentration of light hydrocarbon increased in gas phase, that shifted the hydrate equilibrium condition to a lower temperature. In 
addition, the results showed that $2250 \mathrm{ppm}$ mSA-AFP lowered the onset nucleation temperature from 14.3 to $8.5{ }^{\circ} \mathrm{C}$, which suggested it has a good effectiveness when coexisting with oil and salts. The adding of $2250 \mathrm{ppm}$ starch, glycine and chitosan decreased the onset nucleation temperatures to 13.2, 11.8 and $12.6{ }^{\circ} \mathrm{C}$, respectively. The inhibition strength of tested inhibitors in (salt water $+15 \%$ crude oil) system are shown in Figure 5, it can be seen that the performance of various inhibitors follow the similar trend with that in pure water or salt water: $\operatorname{starch}\left(1.1^{\circ} \mathrm{C}\right)<\operatorname{chitosan}\left(1.7^{\circ} \mathrm{C}\right)<\operatorname{glycine}\left(2.5^{\circ} \mathrm{C}\right)$ $<\operatorname{PVP}\left(3.9^{\circ} \mathrm{C}\right)<\operatorname{mSA}-\operatorname{AFP}\left(5.8^{\circ} \mathrm{C}\right)$. By analyzing the results, it can be seen that the coexistence of crude oil and most inhibitors present slightly cumulative effect, however, the inhibition strength of PVP in crude oil system reduced $1.0{ }^{\circ} \mathrm{C}$ compared to that in salt water. This is unexpected and the reason might be that PVP reduced the interfacial tension, which can contribute to SNG diffusion in oil phase and promote hydrate nucleation. This case is in accordance with Sharifi's investigation, ${ }^{32}$ they tested the performance of PVP in salt solutions and with heptane, it was observed that the adding of n-heptane to PVP solutions increased hydrate nucleation temperature. In the system containing crude oil, $2250 \mathrm{ppm}$ mSA-AFP still has better inhibition activity than PVP at the same concentration.

It was well known that the solution experienced hydrate formation and decomposition process would have memory effect and make hydrate reform more easily, therefore, the memory solutions are tested in this study and the results are shown in Table 6. By comparing the onset nucleation temperatures of memory solutions with those of fresh solutions, it was found that there was few remarkable changes between them (their difference are in 0.2-0.4 ${ }^{\circ} \mathrm{C}$ and essentially within experimental error). In addition, the inhibition strength of various chemicals in memory solutions are shown in Figure 5, it can be seen that their effectiveness have no significant difference with those of fresh solutions. Zeng et al. ${ }^{16-18}$ reported that AFP can eliminate the memory effect of sI and sII hydrate reformation process, they suggest that AFP molecules can adsorb on impurity particles surface to rapidly form a rigid film and block the nucleating sites, and this ability distinguishes AFPs from other 
synthetic inhibitors. However, for other four chemicals (PVP, starch, chitosan and glycine), there was few reports of this aspect in literatures. Therefore, we cannot conclude that these tested chemicals have ability to weaken memory effect. The reason might be that SNG hydrate structures in memory solutions are completely destroyed in heating process (since the temperatures are increased to $25{ }^{\circ} \mathrm{C}$, which made the solutions do not have residual nucleation points). More tests need to be performed in the future to investigate the memory effect.

Table 5. The average onset nucleation temperature of SNG hydrate in fresh solution (salt water +15 vol\% crude oil).

\begin{tabular}{cccccc}
\hline Chemicals & $\begin{array}{c}\text { Number of } \\
\text { tests }\end{array}$ & Concentration $(\mathrm{ppm})$ & $T_{\mathrm{o}}\left({ }^{\circ} \mathrm{C}\right)$ & $\mathrm{SD}\left({ }^{\circ} \mathrm{C}\right)$ & $\mathrm{RSD}(\%)$ \\
\hline No KHIs & 5 & - & 14.3 & 0.23 & 1.59 \\
mSA-AFP & 1 & 2250 & 8.5 & - & - \\
chitosan & 5 & 2250 & 12.6 & 0.22 & 1.76 \\
starch & 5 & 2250 & 13.2 & 0.12 & 0.93 \\
PVP & 9 & 2250 & 10.4 & 0.17 & 1.68 \\
glycine & 5 & 2250 & 11.8 & 0.17 & 1.43 \\
\hline
\end{tabular}

${ }^{*} T_{\mathrm{o}}$ is the average onset nucleation temperature, SD is standard deviation, RSD is the relative standard deviation.

Table 6. The average onset nucleation temperature of SNG hydrate in memory solution (salt water +15 vol\% crude oil).

\begin{tabular}{cccccc}
\hline Chemicals & $\begin{array}{c}\text { Number of } \\
\text { tests }\end{array}$ & Concentration $(\mathrm{ppm})$ & $T_{\mathrm{o}}\left({ }^{\circ} \mathrm{C}\right)$ & $\mathrm{SD}\left({ }^{\circ} \mathrm{C}\right)$ & $\mathrm{RSD}(\%)$ \\
\hline No KHIs & 5 & - & 14.5 & 0.28 & 1.93 \\
mSA-AFP & 1 & 2250 & 8.8 & - & - \\
chitosan & 5 & 2250 & 13.0 & 0.20 & 1.56 \\
starch & 5 & 2250 & 13.6 & 0.27 & 1.95 \\
PVP & 9 & 2250 & 10.8 & 0.14 & 1.31 \\
glycine & 5 & 2250 & 12.1 & 0.23 & 1.87 \\
\hline
\end{tabular}

${ }^{*} T_{\mathrm{o}}$ is the average onset nucleation temperature, SD is standard deviation, RSD is the relative standard deviation. 


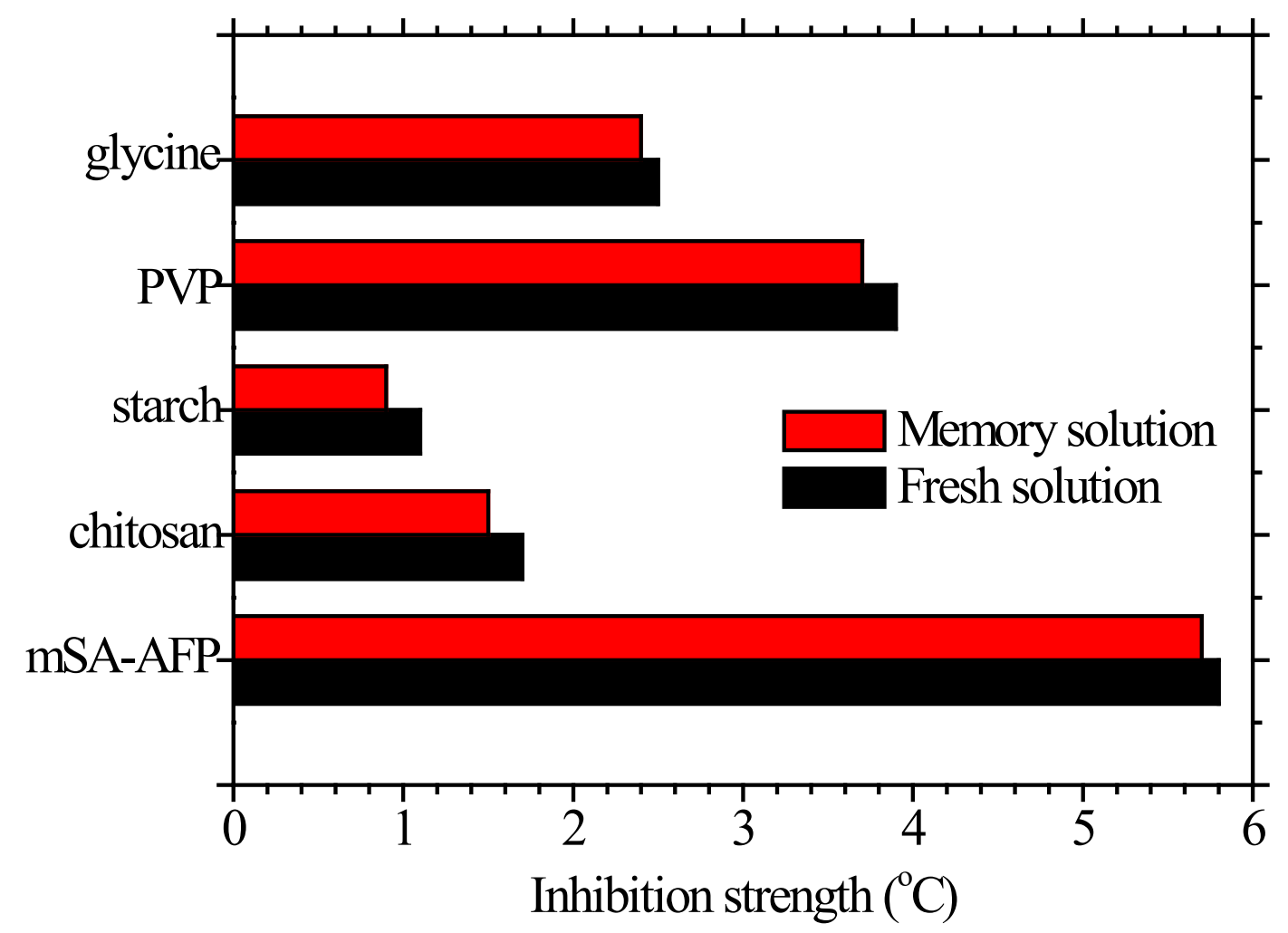

Figure 5. The strength of various chemicals in fresh and memory (salt water +15 vol\% crude oil) system.

\subsection{SNG hydrate growth rate of for the system containing inhibitors}

To investigate and compare the growth rate of SNG hydrate in various system, the pressure profiles are normalized through dividing the pressure at any time in hydrate formation process by the onset nucleation pressure. Typical pressure curves in the (salt water +15 vol $\%$ crude oil) system are shown in Figure 6. SNG hydrate crystal growth rate can be expressed as the slope of pressure curves, it can be seen that the non-inhibited system has a higher growth rate than the inhibited systems in the first 50 min, which indicated the tested inhibitors can delay SNG hydrate growth rate. The reason might be that the KHIs lowered the transport rate and adsorption capacity of guest molecules to hydrate surface. ${ }^{33-38}$ Gordienko et al. ${ }^{39}$ demonstrated that AFPs can adhere to THF hydrate surface, they suggested that both commercial and biological inhibitors likely inhibit hydrate growth by an adsorption-inhibition mechanism. In addition, the amount of SNG hydrate formation can be estimated 
by the pressure drops, from Figure 6, it can be observed that the system containing 2250 ppm PVP (pressure drop is $14.1 \%$ ) present a higher hydrate production than non-inhibited system (pressure drop is $12.6 \%$ ) although they can delay hydrate nucleation. It should be noted this case before application because it can increase hydrate production. However, the system containing other inhibitors (mSA-AFP, starch, chitosan and glycine) showed lower hydrate production (pressure drops are $7.3 \%, 11.4 \%, 9.4 \%$ and $12.4 \%$, respectively). This case is advantageous as KHIs since the hydrate production is relatively less and can be easily decomposed once the KHIs lose efficacy in practical application. Al-Adel et al. ${ }^{20}$ investigated the effect of AFPs on the crystal growth, they believed that AFPs can act as hydrate inhibitor or promoter, mainly depending on the experimental temperature and pressure.

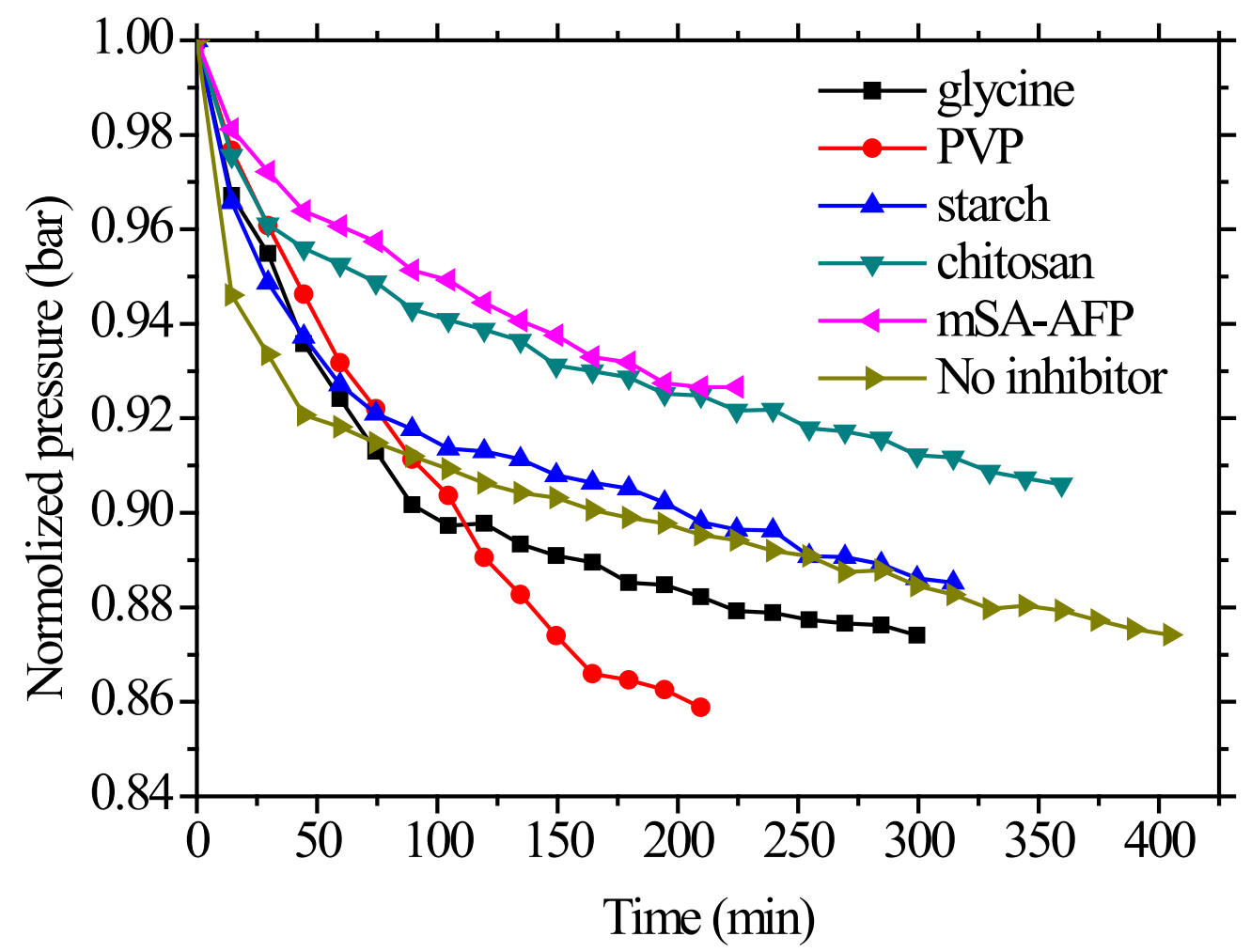

Figure 6. Normalized pressure profiles in the (salt water +15 vol\% crude oil) system.

\subsection{SNG hydrate decomposition of for the system containing inhibitors}


In industry, hydrate formation is unavoidable in the case of long shut-in periods or high sub-cooling, therefore the decomposition of SNG hydrate in (salt water +15 vol\% crude oil) system was investigated by heating from 1 to $25{ }^{\circ} \mathrm{C}$ at $0.1{ }^{\circ} \mathrm{C} / \mathrm{min}$ in this study. Pressure profiles are normalized to compare the decomposition process of SNG hydrate in the presence of different inhibitors. Typical pressure changes in the (salt water +15 vol\% crude oil) system are shown in Figure 7, it can be seen that the SNG hydrate decomposition time was much shorter compared with formation time, and the hydrate can decompose completely within 40 min even in the presence of various inhibitors. Similarly with the formation process, the amount of hydrate decomposed can be estimated by pressure rise, and the decomposition rate can be seen from the slope of pressure curves. It is obviously that the system with 2250 ppm PVP showed a longer decomposition time, we speculated that it was because the SNG hydrate has a larger production in the system containing PVP, leading it to need more time to fully decompose. In addition, the system containing $2250 \mathrm{ppm}$ glycine present a faster decomposition rate. The onset decomposition temperatures in various systems are shown in Figure 8, it can be seen that the adding of $3.5 \mathrm{wt} \% \mathrm{NaCl}$ decreased the average onset decomposition temperature of SNG hydrate $0.8{ }^{\circ} \mathrm{C}$ compared to pure water $\left(22.9{ }^{\circ} \mathrm{C}\right)$, which indicated that salts can promote SNG hydrate decomposition. In addition, the average onset decomposition temperature of SNG hydrate in (salt water $+15 \%$ crude oil $)$ system $\left(21.4{ }^{\circ} \mathrm{C}\right)$ lowered $1.5^{\circ} \mathrm{C}$ than that in salt water $\left(22.9{ }^{\circ} \mathrm{C}\right)$, one reason might be that some components in crude oil can decrease SNG hydrate stability and promote hydrate decomposition, another possible reason is that the existing of crude oil improved the mass transfer rate in hydrate decomposition. Becke et al. ${ }^{40}$ tested the effect of liquid hydrocarbons on natural gas hydrate equilibrium, it was found that the hydrate stability temperature would decrease in the presence of crude oil. In addition, 2250 ppm PVP and glycine slightly increased the onset decomposition temperature of SNG hydrate in (salt water $+15 \%$ crude oil) system. Starch or chitosan essentially did not show effect on the onset decomposition temperature for the system containing crude oil, while 
mSA-AFP decreased it from $21.4{ }^{\circ} \mathrm{C}$ to $20.2{ }^{\circ} \mathrm{C}$, this is expected because mSA-AFP can make hydrate decomposition more easily once they lose efficacy in practical application. For the pure water and salt water system in the presence of various inhibitors, similar tendency was observed.

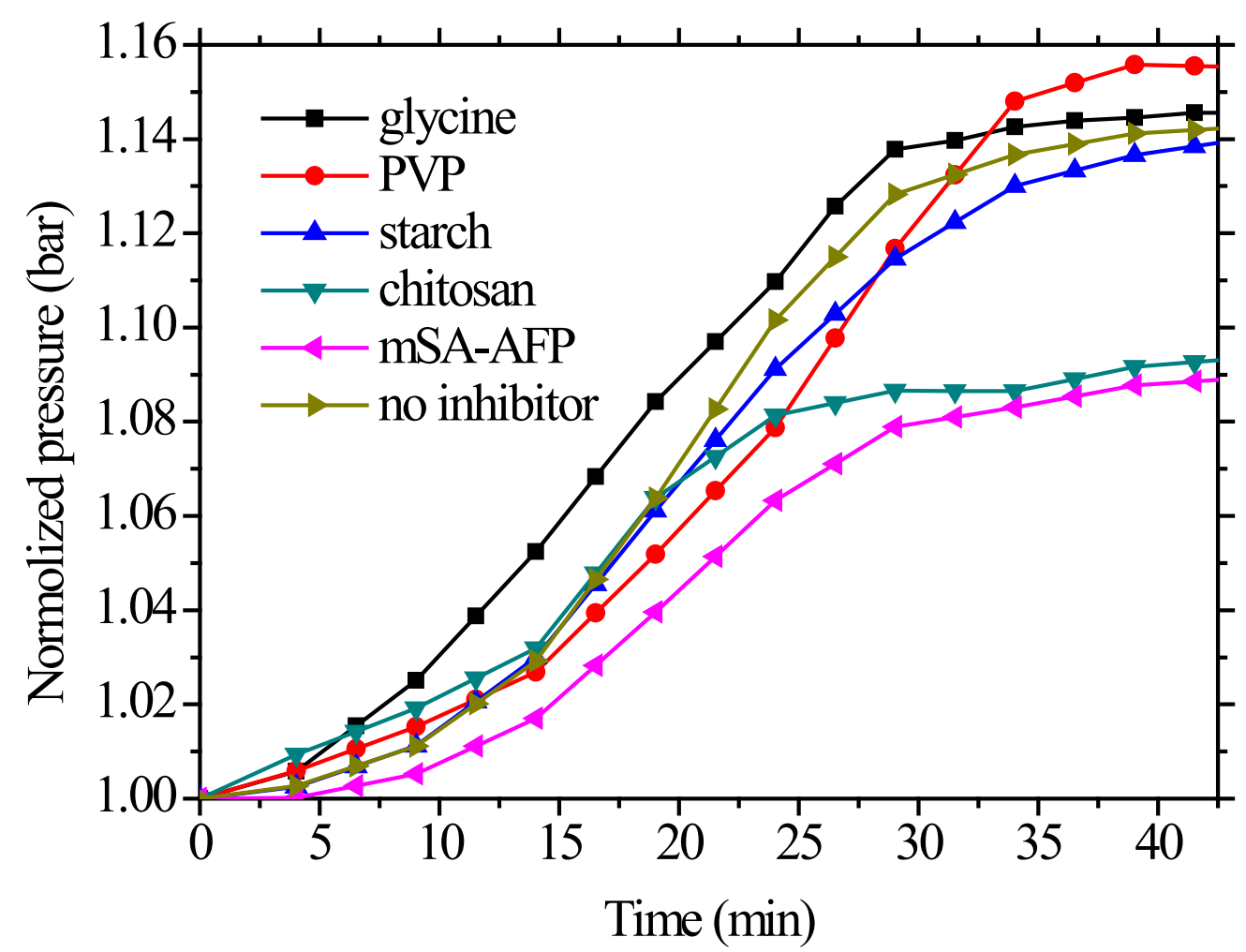

Figure 7. Normalized hydrate dissociation profiles in the (salt water +15 vol $\%$ crude oil) system. 


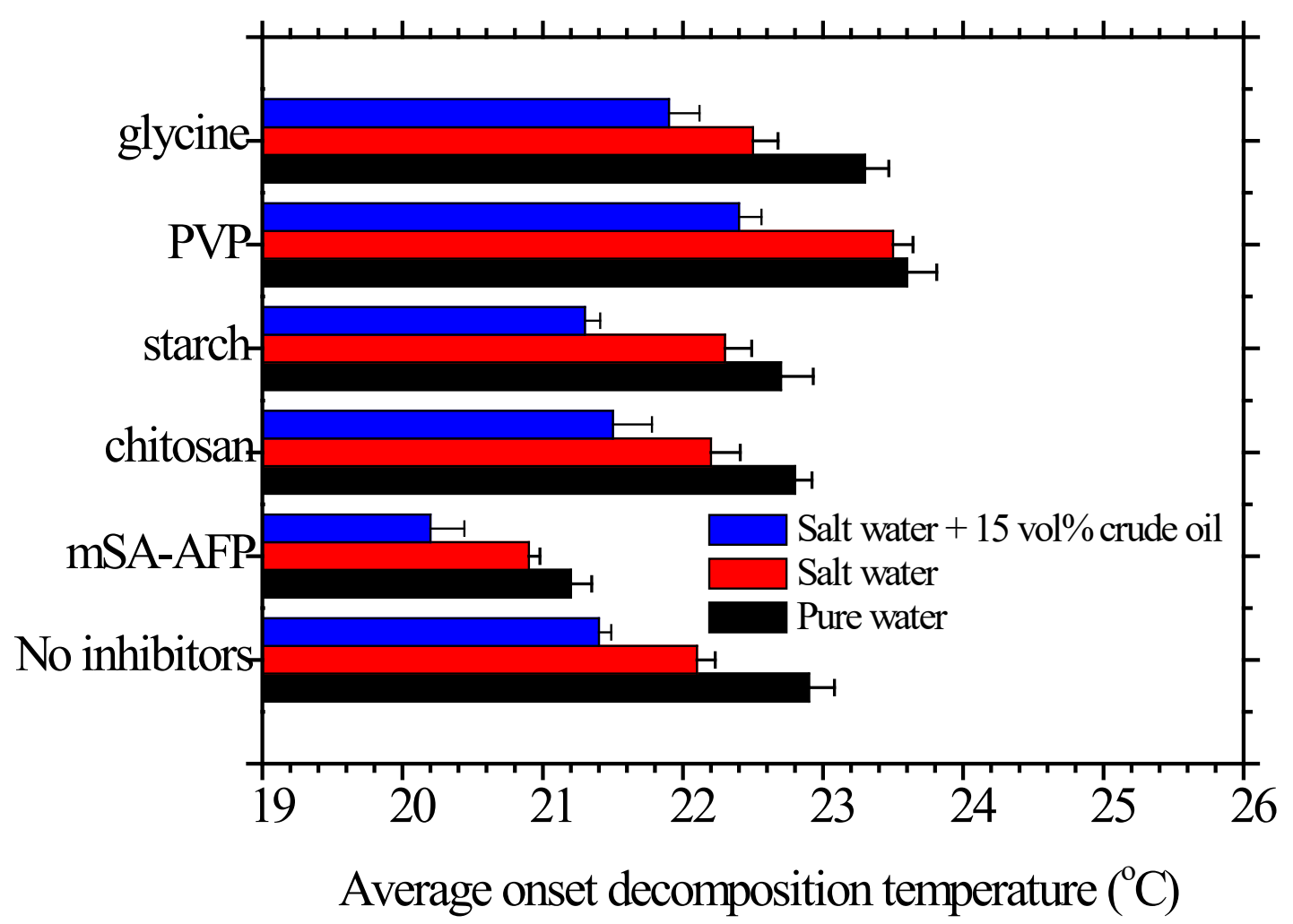

Figure 8. The average onset decomposition temperature of SNG hydrate in various systems (error bars represents standard deviation).

\subsection{The test of various inhibitors with DSC}

For testing whether the results obtained from rocking cell experiments have apparatus dependence, the inhibition performance of mSA-AFP as well as other chemicals on SNG hydrate nucleation was evaluated using a micro differential scanning calorimeter ( $\mu$-DSC). The detailed operation procedure of $\mu$-DSC experiments has been reported in our previous studies, ${ }^{41,42}$ it is briefly introduced as follows: three capillary tubes loaded with $3.0 \mathrm{mg}$ solution were placed in a sample cell, pressurizing to 100 bar with SNG, cooling from $25{ }^{\circ} \mathrm{C}$ to $-35{ }^{\circ} \mathrm{C}$ at $0.25{ }^{\circ} \mathrm{C} \cdot \mathrm{min}^{-1}$, then heating from $-35{ }^{\circ} \mathrm{C}$ to $25{ }^{\circ} \mathrm{C}$ at the same rate. Figure 9 showed the typical heat flow changes in salt water system containing $2250 \mathrm{ppm}$ mSA-AFP. In this work, the crude oil system were not tested with $\mu$-DSC, because the sample usage is relatively less and it is difficult to perform experiments using this method. SNG hydrate nucleation 
can be identified by exothermic peaks in cooling cycle, it was found there are more than one exothermic peak occurred, the reason might be that the capillary tubes are separated, a nucleation in one of tube cannot affect others. It should be noted that the onset nucleation temperature obtained by $\mu$-DSC was calculated with the first exothermic peak which indicated the earliest nucleation point. It can be seen that the onset nucleation temperature of the mSA-AFP solution occurred at $-22.4{ }^{\circ} \mathrm{C}$, which was lower $5.5^{\circ} \mathrm{C}$ than that of the salt water $\left(-16.9{ }^{\circ} \mathrm{C}\right)$. The measured values of onset nucleation temperature using $\mu$-DSC are different from those with the rocking cell apparatus, the reason might be that the $\mu$-DSC tests were conducted under static conditions while the rocking cell experiments were performed under stirring conditions, which speed up the hydrate nucleation reaction at some extent. The adding of $2250 \mathrm{ppm} \mathrm{mSA}-\mathrm{AFP}$ in salt water decreased the exothermic peaks area of SNG hydrate formation, which indicates less hydrate formed in mSA-AFP solution. In heating cycle, the endothermic peak at $0{ }^{\circ} \mathrm{C}$ is formed by ice melting, and another is cause by hydrate decomposition. It can be observed that the peak position of hydrate decomposition in mSA-AFP solution occurred earlier than that of salt water, which suggested the SNG hydrate formed by mSA-AFP solution was more easily decomposed. The inhibition strength of mSA-AFP as well as other chemicals (Figure 10) measured by $\mu$-DSC are essentially same with those obtained from rocking cell experiments, which indicated our tests have good reliability. It is evident from the results obtained in both $\mu$-DSC and rocking cell experiments that mSA-AFP is effective in delaying SNG hydrate nucleation. 


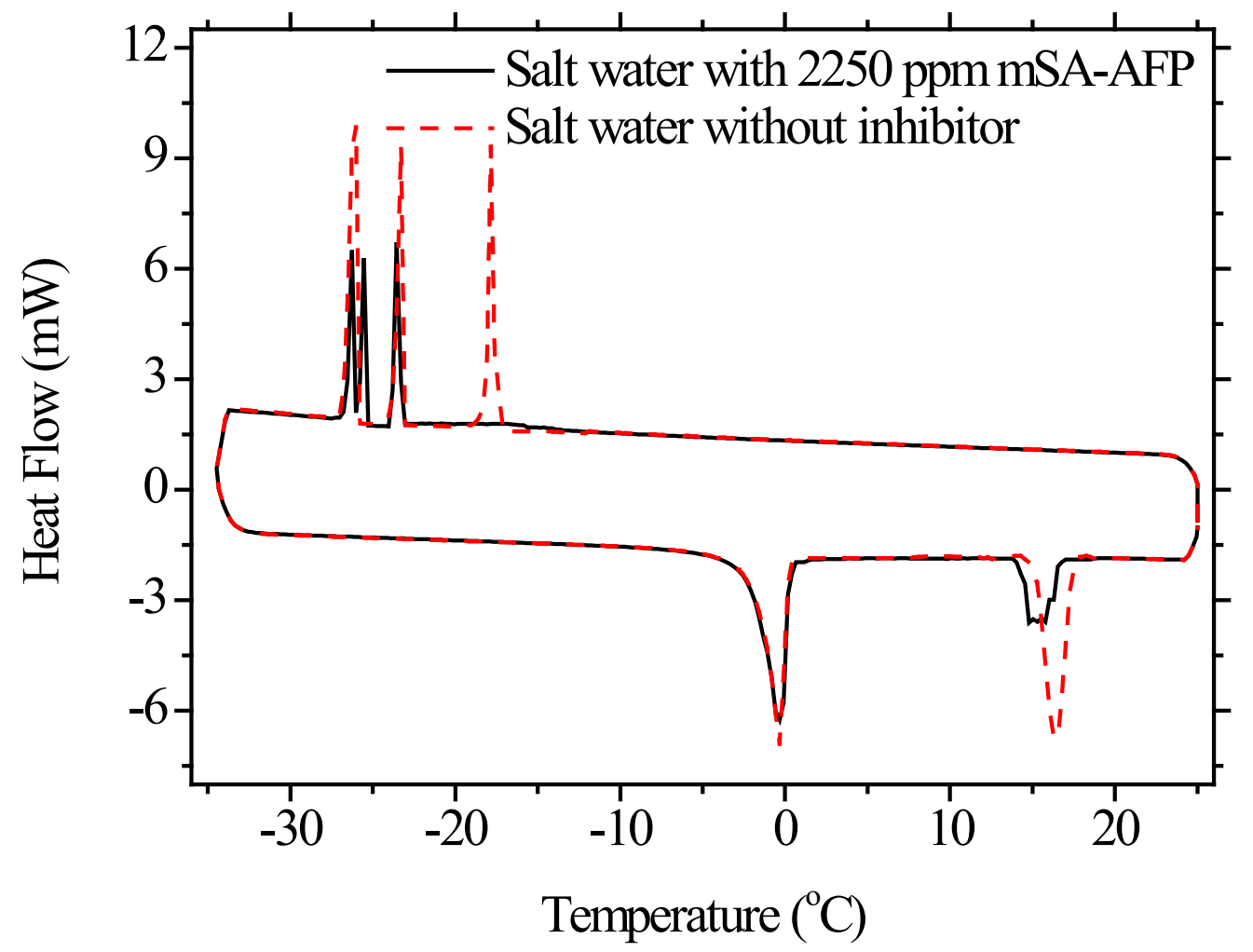

Figure 9. Typical heat flow and temperature changes obtained during SNG hydrate formation and dissociation. 


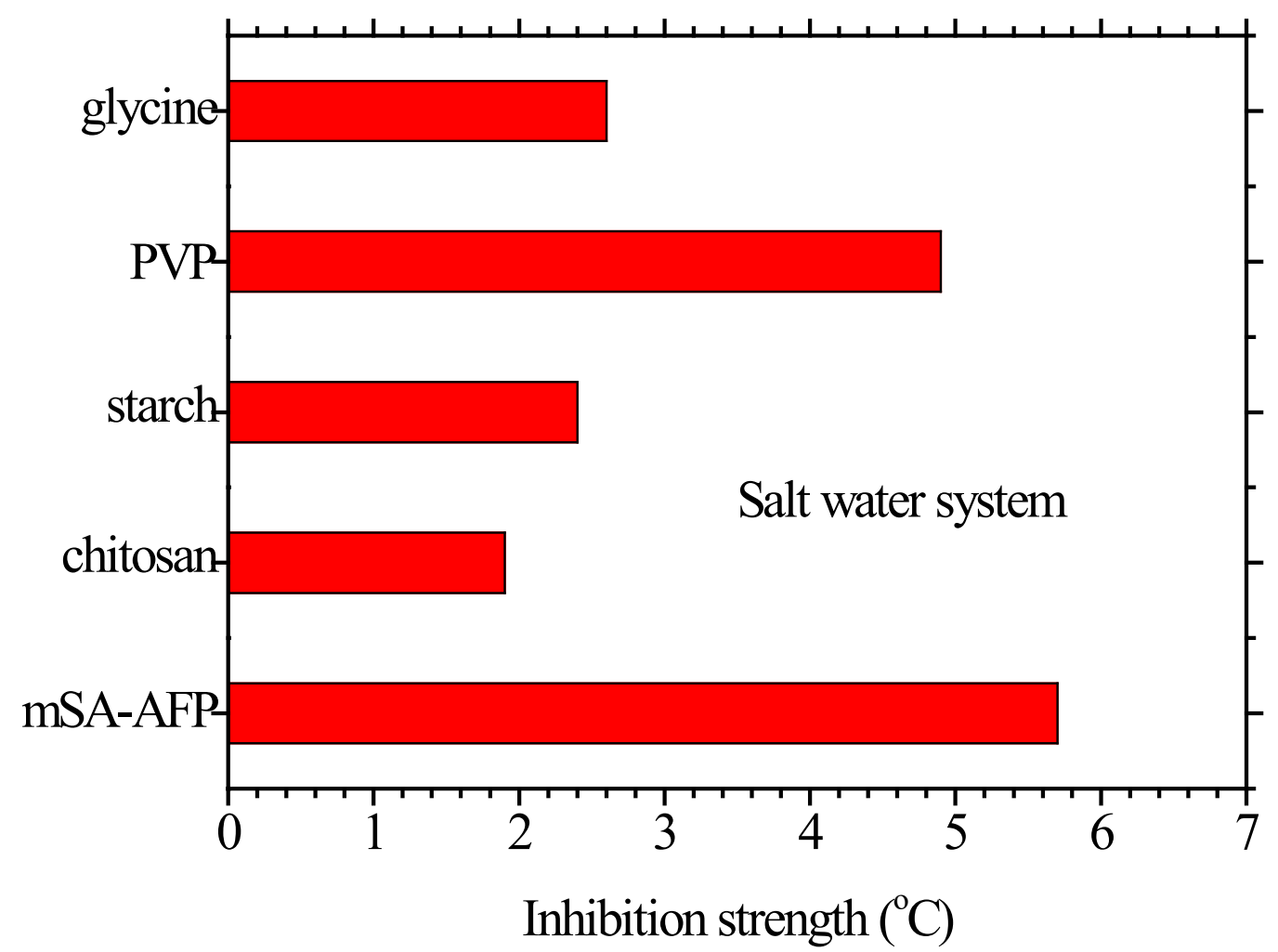

Figure 10. The inhibition strength of various chemicals in salt water system evaluated by $\mu$-DSC.

\section{Conclusion}

In this study, the effectiveness of a new antifreeze protein (mSA-AFP) as well as three environment friendly inhibitors (starch, chitosan and glycine) on inhibiting SNG hydrate nucleation in the system containing salts and crude oil was investigated using a rocking cell apparatus. The inhibition performance of various chemicals was compared to that of the commercial inhibitor PVP. The adding of $2250 \mathrm{ppm} \mathrm{mSA}$-AFP in (salt water +15 vol\% crude oil) system decreased the onset nucleation temperature of SNG hydrate $5.8{ }^{\circ} \mathrm{C}$. The inhibition strength of various chemicals has the same tendency and can be ranked as follows: starch $<$ chitosan $<$ glycine $<$ PVP $<$ mSA-AFP. It was found that mSA-AFP can decrease the SNG hydrate growth rate and production as well as the onset decomposition temperature, however, PVP increased hydrate production and the onset decomposition temperature in (salt water +15 vol $\%$ crude oil) system, it should be noted this case before practical 
application. For eliminating the dependence on experimental apparatus, the performance of various inhibitors on delaying SNG hydrate nucleation in salt water system were tested using a micro differential scanning calorimeter, the results are consistent with those obtained from rocking cell apparatus. These results confirmed that mSA-AFP can effectively inhibit SNG hydrate formation and growth in the field conditions as a green hydrate inhibitor.

\section{AUTHOR INFORMATION}

\section{Corresponding Author}

*Telephone: +45 4525 2867. Fax: +45 4588 2258. E-mail: nvs@kt.dtu.dk.

\section{References}

[1] Englezos, P. Clathrate hydrates. Ind. Eng. Chem. Res. 1993, 32, 1251-1274.

[2] Sloan, E. D.; Koh, C. A. Clathrate Hydrates of Natural Gases, third ed., CRC Press, Taylor \& Francis Group, New York, 2008.

[3] Hammerschmidt, E. G. Formation of gas hydrates in natural gas transmission lines. Ind. Eng. Chem. 1934, $26(8), 851-855$.

[4] Graham, B.; Reilly, W. K.; Beinecke, F.; Boesch, D. F.; Garcia, T. D.; Murray, C. A.; Ulmer, F. Deep Water: The Gulf Oil Disaster and the Future of Offshore Drilling (Report to the President); United States Government Publishing Office: Washington, D.C., 2011.

[5] Koh, C. A. Towards a fundamental understanding of natural gas hydrates. Chem. Soc. Rev. 2002, $31,157-167$. 
[6] Sloan, E. D. Fundamental principles and applications of natural gas hydrates. Nature 2003, 426, $353-363$.

[7] Tohidi, B.; Anderson, R.; Mozaffar, H.; Tohidi, F. The Return of Kinetic Hydrate Inhibitors. Energy Fuels 2015, 29 (12), 8254-8260.

[8] Perrin, A.; Musa, O. M.; Steed, J. W. The chemistry of low dosage clathrate hydrate inhibitors. Chem. Soc. Rev. 2013, 42, 1996-2015.

[9] Kelland, M. A. History of the development of low dosage hydrate inhibitors. Energy \& Fuels 2006, 20 (3), 825-847.

[10] Kelland, M. A. Production Chemicals for the Oil and Gas Industry, 2nd ed.; CRC Press: Boca Raton, FL, 2014.

[11] Sa, J. H.; Kwak, G. H.; Lee, B. H.; Park, D. H.; Han, K.; Lee, K. H. Hydrophobic amino acids as a new class of kinetic inhibitors for gas hydrate formation. Scientific Reports 2013, 3, 2428-2435.

[12] Xu, S.; Fan, S.; Fang, S.; Lang, X.; Wang, Y.; Chen, J. Pectin as an Extraordinary Natural Kinetic Hydrate Inhibitor. Scientific Reports 2016, 6, 23220-23227.

[13] Lee, J. D.; Wu, H. J.; Englezos, P. Cationic starches as gas hydrate kinetic inhibitors. Chem. Eng. Sci. 2007, 62 (23), 6548-6555.

[14] Xu, Y.; Yang, M.; Yang, X. Chitosan as green kinetic inhibitors for gas hydrate formation. $J$. Nat. Gas Chem. 2010, 19, 431-435.

[15] Jensen, L.; Thomsen, K.; Solms, N. V. Inhibition of Structure I and II Gas Hydrates using Synthetic and Biological Kinetic Inhibitors. Energy Fuels 2011, 25, 17-23. 
[16] Zeng, H.; Wilson, L. D.; Walker, V. K.; Ripmeester, J. A. Effect of Antifreeze Proteins on the Nucleation, Growth, and the Memory Effect during Tetrahydrofuran Clathrate Hydrate Formation. $J$. Am. Chem. Soc. 2006, 128 (9), 2844-2850.

[17] Zeng, H.; Wilson, L. D.; Walker, V. K.; Ripmeester, J. A. The inhibition of tetrahydrofuran clathrate-hydrate formation with antifreeze protein. Can. J. Phys. 2003, 81 (1-2), 17-24.

[18] Zeng, H.; Moudrakovski, I. L.; Ripmeester, J. A.; Walker, V. K. Effect of antifreeze protein on nucleation, growth and memory of gas hydrates. AIChE J. 2006, 52 (9), 3304-3309.

[19] Ohno, H.; Susilo, R.; Gordienko, R.; Ripmeester, J. A.; Walker, V. K. Interaction of antifreeze proteins with hydrocarbon hydrates. Chem.-Eur. J. 2010, 16 (34), 10409-10417.

[20] Al-Adel, S.; Dick, J. A. G.; El-Ghafari, R.; Servio, P. The Effect of Biological and Polymeric Inhibitors on Methane Gas Hydrate Growth Kinetics. Fluid Phase Equilib. 2008, 267 (1), 92-98.

[21] Daraboina, N.; Linga, P.; Ripmeester, J.; Walker, V. K.; Englezos, P. Natural Gas Hydrate Formation and Decomposition in the Presence of Kinetic Inhibitors. 2. Stirred Reactor Experiments. Energy Fuels 2011, 25 (10), 4384-4391.

[22] Daraboina, N.; Ripmeester, J.; Walker, V. K.; Englezos, P. Natural Gas Hydrate Formation and Decomposition in the Presence of Kinetic Inhibitors. 1. High Pressure Calorimetry. Energy Fuels 2011, 25 (10), 4392-4397.

[23] Daraboina, N.; Ripmeester, J.; Walker, V. K.; Englezos, P. Natural Gas Hydrate Formation and Decomposition in the Presence of Kinetic Inhibitors. 3. Structural and Compositional Changes. Energy Fuels 2011, 25 (10), 4398-4404. 
[24] Daraboina, N.; Moudrakovski, I.; Ripmeester, J. A.; Walker, V. K.; Englezos, P. Assessing the Performance of Commercial and Biological Gas Hydrate Inhibitors Using Nuclear Magnetic Resonance Microscopy and a Stirred Autoclave. Fuel 2013, 105, 630-635.

[25] Perfeldt, C. M.; Chua, P. C.; Daraboina, N.; Friis, D.; Kristiansen, E.; Ramløv, H.; Woodley, J. M.; Kelland, M. A.; Solms, N. V. Inhibition of Gas Hydrate Nucleation and Growth: Efficacy of an Antifreeze Protein from the Longhorn Beetle Rhagium mordax. Energy Fuels, 2014, 28 (6), 36663672.

[26] Xiao, C.; Adidharma, H. Dual function inhibitors for methane hydrate. Chem. Eng. Sci. 2009, 64 (7), 1522-1527.

[27] Villano, L.; Kelland, M. A. An investigation into the kinetic hydrate inhibitor properties of two imidazolium-based ionic liquids on Structure II gas hydrate. Chem. Eng. Sci. 2010, 65 (19), 53665372.

[28] Kristiansen, E.; Wilkens, C.; Vincents, B.; Friis, D.; Lorentzen, A. B.; Jenssen, H.; LøbnerOlesen, A.; Ramlov, H. Hyperactive Antifreeze Proteins from Longhorn Beetles: Some Structural Insights. J. Insect Physiol 2012, 58 (11), 1502-1510.

[29] Daraboina, N.; Malmos, C.; Solms, N. V. Synergistic kinetic inhibition of natural gas hydrate formation. Fuel 2013, 108, 749-757.

[30] Daraboina, N.; Pachitsas, S.; Solms, N. V. Experimental validation of kinetic inhibitor strength on natural gas hydrate nucleation. Fuel 2015, 139, 554-560.

[31] Daraboina, N.; Pachitsas, S.; Solms, N. V. Natural gas hydrate formation and inhibition in gas/crude oil/aqueous systems. Fuel 2015, 148, 186-190. 
[32] Sharifi, H.; Ripmeester, J.; Walker, V. K.; Englezos, P. Kinetic inhibition of natural gas hydrates in saline solutions and heptane. Fuel 2014, 117, 109-117.

[33] Anderson, B. J.; Tester, J. W.; Borghi, G. P.; Trout, B. L. Properties of inhibitors of methane hydrate formation via molecular dynamics simulations. J. Am. Chem. Soc. 2005, 127, 17852-17862.

[34] Moon, C.; Taylor, P. C.; Rodger, P. M. Computer modelling of gas hydrate formation. Proceedings of the 4th International Conference on Gas Hydrates, Yokohama, Japan, May 19-23, $2002 ; 665-668$.

[35] Moon, C.; Taylor, P. C.; Rodger, P. M. Molecular dynamics study of gas hydrate formation. J. Am. Chem. Soc. 2003, 125 (16), 4706-4707.

[36] Kumar, R.; Lee, J. D.; Song, M.; Englezos, P. Kinetic inhibitor effects on methane/propane clathrate hydrate-crystal growth at the gas/water and water/n-heptane interfaces. J. Cryst. Growth 2008, $310(6), 1154-1166$.

[37] Carstensen, A.; Creek, J. L.; Koh, C. A. Investigating the performance of clathrate hydrate inhibitors using in situ Raman spectroscopy and differential scanning calorimetry. Am. Mineral. 2004, 89 (8-9), 1215-1220.

[38] King Jr, H. E.; Hutter, J. L.; Lin, M. Y.; Sun, T. Polymer conformations of gas-hydrate kinetic inhibitors: a small-angle neutron scattering study. J. Chem. Phys. 2000, 112 (5), 2523-2532.

[39] Gordienko, R.; Ohno, H.; Singh, V. K.; Jia, Z. C.; Ripmeester, J. A.; Walker, V. K. Towards a green hydrate inhibitor: imaging antifreeze proteins on clathrates. PLOS ONE 2010, 5 (2), e8953.

[40] Becke, P.; Kessel, D.; Rahimian, I. Influence of liquid hydrocarbons on gas hydrate equilibrium. European petroleum conference held in Cannes, France, SPE 25032, 1992. 
[41] Daraboina, N.; Malmos, C.; Solms, N. V. Investigation of Kinetic Hydrate Inhibition Using a High Pressure Micro Differential Scanning Calorimeter. Energy Fuels 2013, 27 (10), 5779-5786.

[42] Mu, L.; Solms, N. V. Hydrate thermal dissociation behavior and dissociation enthalpies in methane-carbon dioxide swapping process. J. Chem. Thermodyn. 2018, 117, 33-42. 